\title{
Synthesis, anticancer activity, and docking study of $N$-acetyl pyrazolines from veratraldehyde
}

\author{
Tutik Dwi Wahyuningsih*, Artania Adnin Tri Suma, Endang Astuti \\ Department of Chemistry, UGM, Sekip Utara, Yogyakarta, Indonesia.
}

\begin{tabular}{l}
\hline ARTICLE INFO \\
\hline Received on: 13/09/2018 \\
Accepted on: 01/02/2019 \\
Available online: 30/03/2019 \\
\hline Key words: \\
Cytotoxic activity, N-acetyl \\
pyrazoline, chalcone, docking \\
molecule.
\end{tabular}

\begin{abstract}
$N$-acetyl pyrazoline derivatives A-C containing methoxy and chloro/hydroxyl substituents were synthesized and tested for their cytotoxic activities. The precursor chalcones $\mathbf{A}-\mathbf{C}$ which were obtained from the condensation reaction between veratraldehyde and acetophenone derivatives were reacted with hydrazine hydrate in the presence of glacial acetic acid to give pyrazolines $\mathbf{A}-\mathbf{C}$ with excellent yield and purity. Characterization of all products was done using Fourier transform infrared (FTIR), nuclear magnetic resonance (NMR) and gas chromatography-mass spectrometers. (GC-MS). Cytotoxicity evaluation of pyrazolines revealed that pyrazoline $\mathbf{A}$ has moderate activity against breast cancer cell line MCF7 ( $\left.\mathrm{IC}_{50} 40.47 \mu \mathrm{g} / \mathrm{ml}\right)$, breast cancer cell line T47D $\left(\mathrm{IC}_{50} 26.51 \mu \mathrm{g} / \mathrm{ml}\right)$, and cervical cancer cell line $\mathrm{HeLa}\left(\mathrm{IC}_{50} 31.19 \mu \mathrm{g} / \mathrm{ml}\right)$. Pyrazoline $\mathbf{B}$ is inactive against all tested cancer lines $\left(\mathrm{IC}_{50}>100 \mu \mathrm{g} / \mathrm{ml}\right)$. Pyrazoline $\mathbf{C}$ has moderate activity against MCF7 $\left(\mathrm{IC}_{50} 94.02 \mu \mathrm{g} / \mathrm{ml}\right)$, but inactive against T47D and HeLa. Docking study showed the interaction between pyrazolines and EGFR receptor via hydrogen bonds and $\pi$-cation interactions.
\end{abstract}

\section{INTRODUCTION}

Cancer is a group of diseases defined by the rapid, uncontrolled, and pathological proliferation of the abnormal cells (Karabacak et al., 2015). Globally, following cardiovascular disorders, cancer is the second-leading disease that causes death (Patel et al., 2011). In 2013, the two types of cancer with the most cases which occurred in Indonesia were cervical and breast cancer with 98,692 cases and 61,682 cases, respectively (Kementerian Kesehatan, 2015). Resistance, lack of selectivity, and the occurrence of side effect to chemotherapeutic agents remain challenging problems in the medical field. Therefore, novel anticancer agents must be developed to suppress this issue.

Pyrazolines, a class of electron-rich nitrogen heterocyclic compounds, have versatile uses in the medicinal chemistry. They possess a wide range of pharmacological functions such as anticancer, antitubercular, antimalarial, antibacterial, antifungal, anti-inflammatory, analgesic, anticonvulsant, and antioxidant

\section{*Corresponding Author}

Tutik Dwi Wahyuningsih, Department of Chemistry, UGM, Sekip Utara, Yogyakarta, Indonesia.E-mail: tutikdw@ugm.ac.id activities (Ahmad et al., 2016; Beyhan et al., 2017; Karad et al., 2016; Kumar et al., 2013; Lv et al., 2010; Rani et al., 2012; Viveka et al., 2015).

Molecular docking studies of pyrazoline derivatives against two types of epidermal growth factor receptor kinase, which are epidermal growth factor receptor (EGFR) and human epidermal growth factor receptor 2 (HER-2) were reported (Mubeen et al., 2015; Yang et al., 2013). In many cases, those proteins are often overexpressed in breast and cervical cancer (Masuda et al., 2012; Tian et al., 2016). The molecular docking studies revealed the important factors influencing their activity as anticancer agents that were in the $\mathrm{N}-\mathrm{N}$ bond of the pyrazoline ring and the various functional groups attached to the benzene rings (Yang et al., 2013). Pyrazoline derivatives containing an acetyl group attached to the nitrogen atom, called $N$-acetyl pyrazolines, are reported to produce excellent cytotoxic activity. Moreover, the presence of a methoxy substituent on the benzene B-ring enhanced its activities together with the presence of chloro and hydroxyl substituent on the para position of the benzene A-ring (Sharma et al., 2014).

A well-known method to synthesize pyrazolines is through a cyclocondensation reaction between hydrazines with $\alpha, \beta$-unsaturated aldehydes or ketones. In this method, intermediate 
hydrazones are formed that undergo cyclization in the presence of a cyclizing reagent such as acetic acid to yield pyrazolines (Shaaban et al., 2012).

In the light of the above findings, we aimed to synthesize $\mathrm{N}$-acetyl pyrazoline derivatives bearing methoxy, chloro, and hydroxyl substituents (Fig. 1). Their cytotoxicity was evaluated against breast cancer cell lines (MCF7 and T47D) and the cervical cancer cell line (HeLa) using the 3-(4,5-dimethylthiazol-2-yl)-2,5diphenyltetrazolium bromide (MTT) method.

\section{MATERIALS AND METHODS}

\section{Chemicals}

All chemicals and solvents used were pro analysis grade originated from Merck with no further purification, i.e., 4-chloroacetophenone, 4-hydroxyacetophenone, veratraldehyde, hydrazine hydrate, sodium hydroxide, hydrochloric acid, glacial acetic acid, ethanol, methanol, ethyl acetate, dichloromethane, hexane, and dimethyl sulfoxide (DMSO). Thin layer chromatography was carried out using aluminum plates $20 \times 20 \mathrm{~cm}$ (Merck) coated with silica gel $60 \mathrm{~F}_{254}$. The materials used for the cytotoxicity evaluation were breast cancer cell line (MCF7 and T47D), cervical cancer cell line (HeLa), normal cell line (Vero), Dulbecco's Modified Eagle Medium (DMEM), Medium 199 (M199), 4-(2-hydroxyethyl)-1-piperazineethanesulfonic acid (HEPES), sodium hydrogen carbonate, Fetal Bovine Serum (FBS), penicillin-streptomycin (Pen-Strep), amphotericin B, trypsin-EDTA solution, phosphate buffered saline (PBS) pH 7.4, MTT, and sodium dodecyl sulfate (SDS).

\section{Instrumentations}

All melting points were uncorrected and determined in open capillary tubes by digital melting point apparatus (Electrothermal 9100). Mass spectra and purity of all synthesized compounds were taken from GC-MS spectrometer on Shimadzu QP2010S (EI). IR spectra were recorded with Shimadzu Prestige-21 using $\mathrm{KBr}$ discs. ${ }^{1} \mathrm{H}$ and ${ }^{13} \mathrm{C}$-NMR spectra were

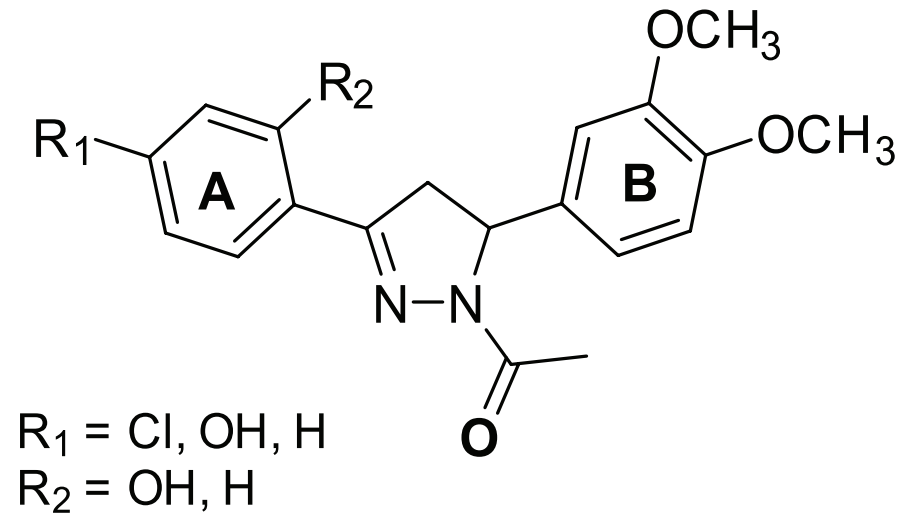

\section{Pyrazoline A-C}

Figure 1. Chemical structure of $N$-acetyl pyrazoline A-C. recorded with JEOL JNMECA $\left[500 \mathrm{MHz}\left({ }^{1} \mathrm{H}\right)\right.$ and $125 \mathrm{MHz}$ $\left({ }^{13} \mathrm{C}\right)$ ] using tetramethylsilane (TMS) as a standard internal. The cytotoxicity evaluation were performed using microwell plate 96 (Biologix), micropipette 2-20 $\mu$ l (VWR brand), micropipette 20 $200 \mu \mathrm{l}$ (VWR brand), micropipette 100-1,000 $\mu$ (AccuBioTech), laminar air flow (Labconco, Purifier Delta Series Class II), a $5 \% \mathrm{CO}_{2}$ incubator (Heraeus), a hemocytometer (Neubauer), an inverted microscope (Axiovert 25), a centrifuge (Janetzki T5, and an enzyme-linked immunosorbent assay (ELISA) reader (BIORAD Benchmark)

Synthesis of (E)-1-(4-chlorophenyl)-3-(3,4-dimethoxyphenyl) prop-2-en-1-one (chalcone A)

To a solution of veratraldehyde $(1.54 \mathrm{~g}, 10 \mathrm{mmol})$ in 30 $\mathrm{ml}$ absolute ethanol, 4-chloroacetophenone $(1.3 \mathrm{ml}, 10 \mathrm{mmol})$ was added with constant stirring. Droplets of 5-ml aqueous sodium hydroxide $30 \%(\mathrm{w} / \mathrm{v})$ were also added into it. The reaction was stirred for 4 hours at the room temperature. Then, the stirring was stopped and the mixture was kept overnight in refrigerator at $15^{\circ} \mathrm{C}$. Vacuum filtration of the mixture was performed to obtain solid precipitate. It was washed with cold water and dried in vacuum desiccator to obtain chalcone A. Yellowish green solid, m.p. $99.2^{\circ} \mathrm{C}-99.6^{\circ} \mathrm{C}$, yield: $93.19 \%$, purity: $97.72 \%$. IR $(\mathrm{KBr})$ $v_{\max }\left(\mathrm{cm}^{-1}\right): 2,954$ (C-H str.), 1,658 (C=O str.), 1,581 and 1,512 (aromatic $\mathrm{C}=\mathrm{C}$ str.), 1,280 (C-O methoxy str.), 1,157 and 1,026 (C-Cl str.), and 987 (trans $\mathrm{C}=\mathrm{C}$ bend.). ${ }^{1} \mathrm{H}-\mathrm{NMR}(500 \mathrm{MHz}) \delta$ (ppm): $3.93\left(3 \mathrm{H}, s, \mathrm{OCH}_{3}\right), 3.95\left(3 \mathrm{H}, s, \mathrm{OCH}_{3}\right), 6.89(1 \mathrm{H}, d, J=$ $8.4 \mathrm{~Hz}, \mathrm{ArH}), 7.14(1 \mathrm{H}, d, J=1.95 \mathrm{~Hz}, \mathrm{ArH}), 7.23(1 \mathrm{H}, d d, J=$ $1.95,8.45 \mathrm{~Hz}, \mathrm{ArH}), 7.33(1 \mathrm{H}, d, J=15.55 \mathrm{~Hz}, \mathrm{C}=\mathrm{CH}$ trans $), 7.46$ $(2 \mathrm{H}, d, J=8.4 \mathrm{~Hz}, \mathrm{ArH}), 7.76(1 \mathrm{H}, d, J=15.55 \mathrm{~Hz}, \mathrm{C}=\mathrm{CH}$ trans $)$, and $7.95(2 \mathrm{H}, d, J=8.45 \mathrm{~Hz}, \mathrm{ArH}) .{ }^{13} \mathrm{C}-\mathrm{NMR}(125 \mathrm{MHz}) \delta(\mathrm{ppm})$ : $56.1\left(\mathrm{OCH}_{3}\right), 56.2\left(\mathrm{OCH}_{3}\right), 110.3(\mathrm{CH}), 111.3(\mathrm{CH}), 119.6(\mathrm{CH})$, $123.5(\mathrm{C}=\mathrm{C}), 127.8(\mathrm{C}), 128.6(\mathrm{CH}), 130.0(\mathrm{CH}), 136.9(\mathrm{C}), 139.1$ (C), $145.7(\mathrm{C}=\mathrm{C}), 149.4(\mathrm{C}), 151.8(\mathrm{C})$, and $189.4(\mathrm{C}=\mathrm{O})$. $\mathrm{MS}(\mathrm{EI})$ m/z: $304\left({ }^{37} \mathrm{Cl}, 30\right), 302\left({ }^{35} \mathrm{Cl}, 80\right), 289\left({ }^{37} \mathrm{Cl}, 10\right), 287\left({ }^{35} \mathrm{Cl}, 40\right)$, $273\left({ }^{37} \mathrm{Cl}, 10\right), 271\left({ }^{35} \mathrm{Cl}, 50\right), 261\left({ }^{37} \mathrm{Cl}, 5\right), 259\left({ }^{35} \mathrm{Cl}, 15\right), 191$ (30), $163(20), 141\left({ }^{37} \mathrm{Cl}, 15\right), 139\left({ }^{35} \mathrm{Cl}, 50\right), 113\left({ }^{37} \mathrm{Cl}, 30\right)$, and $111\left({ }^{35} \mathrm{Cl}, 100\right)$.

\section{Synthesis of (E)-3-(3,4-dimethoxyphenyl)-1-(4-hydroxyphenyl)} prop-2-en-1-one (chalcone $B$ )

A mixture of 4-hydroxyacetophenone $(0.68 \mathrm{~g}, 5 \mathrm{mmol})$ in 10-ml ethanol and 2-ml aqueous $\mathrm{NaOH} 40 \%$ (w/v) was prepared. To this mixture, a solution of veratraldehyde $(0.83 \mathrm{~g}, 5$ $\mathrm{mmol}$ ) in 10-ml ethanol was added dropwise with constant stirring. The reaction mixture was stirred for 48 hours, then it was poured into iced-cold water and acidified with $\mathrm{HCl} \mathrm{10 \%} \mathrm{(v/v).} \mathrm{Vacuum}$ filtration of the mixture was performed to obtain solid precipitate. It was washed with cold water and dried in vacuum desiccator. Recrystallization with ethanol was done to obtain chalcone B. Yellow solid, m.p. $199^{\circ} \mathrm{C}-201^{\circ} \mathrm{C}$, yield: $84.51 \%$, purity: $100 \%$. IR (KBr) $v_{\text {max }}\left(\mathrm{cm}^{-1}\right): 3,240$ (OH str.), 1,643 (C=O str.), 1,597 and 1,512 (aromatic $\mathrm{C}=\mathrm{C}$ str.), 1,265 (C-O methoxy str.), and 987 (trans $\mathrm{C}=\mathrm{C}$ bend.). ${ }^{1} \mathrm{H}-\mathrm{NMR}(500 \mathrm{MHz}) \delta$ (ppm): $3.93(3 \mathrm{H}, s$, $\left.\mathrm{OCH}_{3}\right), 3.95\left(3 \mathrm{H}, s, \mathrm{OCH}_{3}\right), 5.70(1 \mathrm{H}, s, \mathrm{OH}), 6.90(1 \mathrm{H}, d, J=8.4$ 
$\mathrm{Hz}, \mathrm{ArH}), 6.93(1 \mathrm{H}, d, J=9.05 \mathrm{~Hz}, \mathrm{ArH}), 7.15(1 \mathrm{H}, d, J=1.95 \mathrm{~Hz}$, $\mathrm{ArH}), 7.23(1 \mathrm{H}, d d, J=1.95$ and $8.45 \mathrm{~Hz}, \mathrm{ArH}), 7.39(1 \mathrm{H}, d, J=$ $15.55 \mathrm{~Hz}, \mathrm{C}=\mathrm{CH}$ trans $), 7.76(1 \mathrm{H}, d, J=15.55 \mathrm{~Hz}, \mathrm{C}=\mathrm{CH}$ trans $)$, and $8.00(1 \mathrm{H}, d, J=8.45 \mathrm{~Hz}, \mathrm{ArH}) .{ }^{13} \mathrm{C}-\mathrm{NMR}(125 \mathrm{MHz}) \delta(\mathrm{ppm})$ : $55.9\left(\mathrm{OCH}_{3}\right), 55.9\left(\mathrm{OCH}_{3}\right), 110.2(\mathrm{CH}), 111.2(\mathrm{CH}), 115.5(\mathrm{CH})$, $119.9(\mathrm{C}=\mathrm{C}), 123.1(\mathrm{CH}), 128.1(\mathrm{C}), 130.1(\mathrm{C}), 131.1(\mathrm{CH}), 144.4$ $(\mathrm{C}=\mathrm{C}), 149.2(\mathrm{C}), 151.3(\mathrm{C}), 161.9(\mathrm{C})$, and $189.7(\mathrm{C}=\mathrm{O}) . \mathrm{MS}(\mathrm{EI})$ m/z: 284 (100), 269 (50), 253 (40), 241 (30), 191 (20), 121 (90), $93(50)$, and 65 (90).

\section{Synthesis of (E)-3-(3,4-dimethoxyphenyl)-1-(2-hydroxyphenyl)} prop-2-en-1-one (chalcone $\mathrm{C}$ )

A mixture of 2-hydroxyacetophenone $(0.68 \mathrm{~g}, 5 \mathrm{mmol})$ in 5-ml methanol and 5-ml aqueous $\mathrm{NaOH} 40 \%(\mathrm{w} / \mathrm{v})$ was prepared. To this mixture, a solution of veratraldehyde $(0.83 \mathrm{~g}$, $5 \mathrm{mmol}$ ) in 5-ml methanol was added dropwise with constant stirring. The reaction mixture was heated under reflux for 4 hours, then it was poured into iced-cold water. The mixture was acidified with $\mathrm{HCl} 10 \%(\mathrm{v} / \mathrm{v})$ and kept overnight in refrigerator at $15^{\circ} \mathrm{C}$. Vacuum filtration of the mixture was performed to obtain the solid precipitate. It was washed with cold water and dried in vacuum desiccator. Recrystallization with methanol-water (4:1) was done to obtain chalcone $\mathbf{C}$. Yellow solid, m.p. $103.2^{\circ} \mathrm{C}-106.0^{\circ} \mathrm{C}$, yield: 45.07\%, purity: $100 \%$. IR (KBr) $v_{\max }\left(\mathrm{cm}^{-1}\right): 3,448$ (OH str.), $1,635(\mathrm{C}=\mathrm{O}$ str.), 1,573 and 1,512 (aromatic $\mathrm{C}=\mathrm{C}$ str.), 1,265 (C-O methoxy str.), and 979 (trans $\mathrm{C}=\mathrm{C}$ bend.). ${ }^{1} \mathrm{H}-\mathrm{NMR}(500 \mathrm{MHz}) \delta$ (ppm): $3.94\left(3 \mathrm{H}, s, \mathrm{OCH}_{3}\right), 3.96\left(3 \mathrm{H}, s, \mathrm{OCH}_{3}-\right), 6.90(1 \mathrm{H}, d, J$ $=8.45 \mathrm{~Hz}, \mathrm{ArH}), 6.92(1 \mathrm{H}, d, J=7.15 \mathrm{~Hz}, \mathrm{ArH}), 7.02(1 \mathrm{H}, d, J=$ $8.40 \mathrm{~Hz}, \mathrm{ArH}), 7.18(1 \mathrm{H}, s, \mathrm{ArH}), 7.26(1 \mathrm{H}, d, J=8.45 \mathrm{~Hz}), 7.47$ $(1 \mathrm{H}, d, J=8.40 \mathrm{~Hz}, \mathrm{ArH}), 7.50(1 \mathrm{H}, d, J=14.90 \mathrm{~Hz}, \mathrm{C}=\mathrm{CH}$ trans $)$, $7.88(1 \mathrm{H}, d, J=15.55 \mathrm{~Hz}, \mathrm{C}=\mathrm{CH}$ trans $), 7.92(1 \mathrm{H}, d, J=7.75$ $\mathrm{Hz}, \mathrm{ArH})$, and $12.90(1 \mathrm{H}, s, \mathrm{OH}) .{ }^{13} \mathrm{C}-\mathrm{NMR}(125 \mathrm{MHz}) \delta(\mathrm{ppm})$ : $56.1\left(\mathrm{OCH}_{3}\right), 56.1\left(\mathrm{OCH}_{3}\right), 110.4(\mathrm{CH}), 111.3(\mathrm{CH}), 117.9(\mathrm{C}=\mathrm{C})$, $118.7(\mathrm{CH}), 118.9(\mathrm{CH}), 123.8(\mathrm{CH}), 129.7(\mathrm{CH}), 136.3(\mathrm{CH})$, 120.2 (C), 127.7 (C), 145.8 (C=C), 19.4 (C), 151.9 (C), 163.6 (C), and $193.7(\mathrm{C}=\mathrm{O})$. MS (EI) m/z: 284 (35), 269 (5), 253 (10), 241 (5), $121(65), 93$ (40), and 65 (100).

Synthesis of 1-(3-(4-chlorophenyl)-5-(3,4-dimethoxyphenyl)4,5-dihydro-1H-pyrazol-1-yl)ethan-1-one (pyrazoline A)

Hydrazine hydrate $(0.2 \mathrm{ml}, 4 \mathrm{mmol})$ with glacial acetic acid $(15 \mathrm{ml})$ was heated under reflux for 4 hours to give acetyl hydrazine. Chalcone A (3.02 g, $1 \mathrm{mmol})$ was added into it and it was heated under the reflux for another 5 hours. Then, the mixture was poured into iced-cold water and left overnight. Vacuum filtration of the mixture was performed to obtain solid precipitate. Recrystalization with ethanol was done to obtain pyrazoline $\mathbf{A}$. White solid, m.p. $128^{\circ} \mathrm{C}-129.3^{\circ} \mathrm{C}$, yield: $97.28 \%$, purity: $91.90 \%$. $\operatorname{IR}(\mathrm{KBr}) v_{\max }\left(\mathrm{cm}^{-1}\right): 1,660(\mathrm{C}=\mathrm{O}$ str. $), 1,597(\mathrm{C}=\mathrm{N}$ str. $), 1,257(\mathrm{C}-\mathrm{O}$ methoxy str.), 1,142 (C-N str.), and 1,026 (C-Cl str.). ${ }^{1} \mathrm{H}-\mathrm{NMR}(500$ MHz) $\delta(\mathrm{ppm}): 2.42\left(3 \mathrm{H}, s, \mathrm{COCH}_{3}\right), 3.12(1 \mathrm{H}, d d, J=4.50$ and $\left.17.50 \mathrm{~Hz}, \mathrm{CH}_{2}\right), 3.70\left(1 \mathrm{H}, d d, J=12.50\right.$ and $\left.17.50 \mathrm{~Hz}, \mathrm{CH}_{2}\right), 3.82$ $\left(3 \mathrm{H}, s, \mathrm{OCH}_{3}\right), 3.84\left(3 \mathrm{H}, s, \mathrm{OCH}_{3}\right), 5.54(1 \mathrm{H}, d d, J=4.50$ and 12.5 $\mathrm{Hz}, \mathrm{CH}), 6.75$ (3H, $m, \mathrm{ArH}), 7.39(2 \mathrm{H}, d, J=8.40 \mathrm{~Hz}, \mathrm{ArH})$, and $7.76(2 \mathrm{H}, d, J=8.40 \mathrm{~Hz}, \mathrm{ArH}) .{ }^{13} \mathrm{C}-\mathrm{NMR}(125 \mathrm{MHz}) \delta(\mathrm{ppm}): 22.1$ $\left(\mathrm{CH}_{3}\right), 42.5\left(\mathrm{CH}_{2}\right), 56.1(\mathrm{CH}), 60.1\left(\mathrm{OCH}_{3}\right), 60.1\left(\mathrm{OCH}_{3}\right), 109.2$ $(\mathrm{CH}), 111.6(\mathrm{CH}), 117.6(\mathrm{CH}), 126.5(\mathrm{CH}), 129.1(\mathrm{CH}), 128.0(\mathrm{C})$,
134.7 (C), 136.5 (C), 148.7 (C), 149.4 (C), 153.0 (C), and 169.2 $(\mathrm{C}=\mathrm{O})$. MS (EI) m/z: $358\left({ }^{35} \mathrm{Cl}, 5\right), 315\left({ }^{35} \mathrm{Cl}, 15\right), 221\left({ }^{35} \mathrm{Cl}, 25\right)$, $206\left({ }^{35} \mathrm{Cl}, 15\right), 179\left({ }^{35} \mathrm{Cl}, 10\right), 138\left({ }^{35} \mathrm{Cl}, 10\right)$, and $43(100)$.

Synthesis of 1-(5-(3,4-dimethoxyphenyl)-3-(4-hydroxyphenyl)4,5-dihydro-1H-pyrazol-1-yl)ethan-1-one (pyrazoline B)

A mixture of chalcone $\mathbf{B}(0.54 \mathrm{~g}, 2 \mathrm{mmol})$, glacial acetic acid $(10 \mathrm{ml})$, hydrazine hydrate $(0.4 \mathrm{ml}, 10 \mathrm{mmol})$, and $10-\mathrm{ml}$ methanol was heated under the reflux for 6 hours. Then, it was poured into iced-cold water and kept in refrigerator overnight at $15^{\circ} \mathrm{C}$. Vacuum filtration of the mixture was performed to obtain solid precipitate. Column chromatography was performed using dichloromethane-ethyl acetate as an eluent to give pyrazoline $\mathbf{B}$. White solid, m.p. $219^{\circ} \mathrm{C}-221^{\circ} \mathrm{C}$, yield: $88.28 \%$, purity: $83.66 \%$. IR (KBr) $v_{\max }\left(\mathrm{cm}^{-1}\right): 3,425$ (OH str.), 1,651 (C=O str.), 1,604 (C=N str.), 1,234 (C-O methoxy str.), and 1,141 (C-N str.). ${ }^{1} \mathrm{H}-\mathrm{NMR}(500 \mathrm{MHz}) \delta(\mathrm{ppm}): 2.38\left(3 \mathrm{H}, s, \mathrm{COCH}_{3}\right), 2.43(1 \mathrm{H}$, $s, \mathrm{OH}), 3.08\left(1 \mathrm{H}, d d, J=4.55\right.$ and $\left.17.50 \mathrm{~Hz}, \mathrm{CH}_{2}\right), 3.64(1 \mathrm{H}, d d$ $J=11.70$ and $\left.17.50 \mathrm{~Hz}, \mathrm{CH}_{2}\right), 3.79\left(3 \mathrm{H}, s, \mathrm{OCH}_{3}\right), 3.80(3 \mathrm{H}, s$, $\left.\mathrm{OCH}_{3}\right), 5.45(1 \mathrm{H}, d d, J=4.55$ and $11.7 \mathrm{~Hz}, \mathrm{CH}), 6.72(2 \mathrm{H}, d, J$ $=6.45 \mathrm{~Hz}, \mathrm{ArH}), 6.76(1 \mathrm{H}, d, J=9.05 \mathrm{~Hz}, \mathrm{ArH}), 6.81(2 \mathrm{H}, d, J$ $=9.05 \mathrm{~Hz}, \mathrm{ArH})$, and $7.57(2 \mathrm{H}, d, J=6.45 \mathrm{~Hz}, \mathrm{ArH}) .{ }^{13} \mathrm{C}-\mathrm{NMR}$ (125 MHz) $\delta(\mathrm{ppm}): 22.0\left(\mathrm{CH}_{3}\right), 42.7\left(\mathrm{CH}_{2}\right), 55.9\left(\mathrm{OCH}_{3}\right), 56.0$ $\left(\mathrm{OCH}_{3}\right), 59.8(\mathrm{CH}), 109.3(\mathrm{CH}), 111.6(\mathrm{CH}), 115.8(\mathrm{CH}), 115.9$ $(\mathrm{CH}), 117.8(\mathrm{CH}), 128.5(\mathrm{CH}), 128.6(\mathrm{CH}), 123.0(\mathrm{C}), 134.7(\mathrm{C})$, 148.6 (C), 149.3 (C), 159.3 (C), $155.0(\mathrm{C})$, and $169.3(\mathrm{C}=\mathrm{O})$. MS (EI) m/z: 340 (15), 297 (30), 221 (20), 190 (5), 161 (15), 135 (10), 120 (20), 93 (5), and 43 (100).

Synthesis of 1-(5-(3,4-dimethoxyphenyl)-3-(2-hydroxyphenyl)4,5-dihydro-1H-pyrazol-1-yl)ethan-1-one (pyrazoline $\mathrm{C}$ )

A mixture of chalcone $\mathbf{C}(0.142 \mathrm{~g}, 0.5 \mathrm{mmol})$, glacial acetic acid $(10 \mathrm{ml})$ and hydrazine hydrate $(0.2 \mathrm{ml}, 4 \mathrm{mmol})$ was heated under the reflux for 24 hours. Then, it was poured into iced-cold water and kept in refrigerator overnight at $15^{\circ} \mathrm{C}$. Vacuum filtration of the mixture was performed to obtain solid precipitate. Column chromatography was performed using hexane-ethyl acetate as eluent to give pyrazoline $\mathbf{C}$. White solid, m.p. $137.2^{\circ} \mathrm{C}-139.8^{\circ} \mathrm{C}$, yield: 93.14 , purity: $98.96 \%$. IR $(\mathrm{KBr})$ $v_{\max }\left(\mathrm{cm}^{-1}\right): 3,448$ (OH str.), 1,658 (C=O str.), 1,597 (C=N str.), 1,265 (C-O methoxy str.), and 1,142 (C-N str.). ${ }^{1} \mathrm{H}-\mathrm{NMR}(500$ $\mathrm{MHz}) \delta(\mathrm{ppm}): 2.39\left(3 \mathrm{H}, s, \mathrm{COCH}_{3}\right), 3.29(1 \mathrm{H}, d d, J=4.55$ and $\left.17.50 \mathrm{~Hz}, \mathrm{CH}_{2}\right), 3.84\left(3 \mathrm{H}, s, \mathrm{OCH}_{3}\right), 3.86\left(3 \mathrm{H}, s, \mathrm{OCH}_{3}\right), 3.94(1 \mathrm{H}$, $d d, J=12.5$ and $\left.17.50 \mathrm{~Hz}, \mathrm{CH}_{2}\right), 5.50(1 \mathrm{H}, d d, J=4.55$ and 12.5 $\mathrm{Hz}, \mathrm{CH}), 6.76(2 \mathrm{H}, d, J=6.60 \mathrm{~Hz}, \mathrm{ArH}), 6.80(1 \mathrm{H}, d, J=6.50$ $\mathrm{Hz}, \mathrm{ArH}), 6.92(1 \mathrm{H}, d, J=7.80 \mathrm{~Hz}, \mathrm{ArH}), 7.06(1 \mathrm{H}, d, J=8.45$ $\mathrm{Hz}, \mathrm{ArH}), 7.22(1 \mathrm{H}, d, J=8.45 \mathrm{~Hz}, \mathrm{ArH}), 7.35(1 \mathrm{H}, t, \mathrm{ArH})$, and $10.28(1 \mathrm{H}, s, \mathrm{OH}) .{ }^{13} \mathrm{C}-\mathrm{NMR}(125 \mathrm{MHz}) \delta(\mathrm{ppm}): 22.9\left(\mathrm{CH}_{3}\right), 42.9$ $\left(\mathrm{CH}_{2}\right), 56.1\left(\mathrm{OCH}_{3}\right), 56.1\left(\mathrm{OCH}_{3}\right), 58.4(\mathrm{CH}), 109.3(\mathrm{CH}), 111.6$ $(\mathrm{CH}), 117.2(\mathrm{CH}), 117.8(\mathrm{CH}), 120.0(\mathrm{CH}), 128.6(\mathrm{CH}), 132.5$ (CH), 115.3 (C), 133.9 (C), 148.9 (C), 149.4 (C), 157.8 (C), 156.6 (C), and 1,698.1 (C=O). MS (EI) m/z: 340 (50), 325 (5), 298 (30), 297 (65), 281 (35), 267 (10), 161 (55), and 43 (100).

\section{The cytotoxic activity assay}

All cell lines were cultured in $5 \% \mathrm{CO}_{2}$ water-saturated atmosphere at $37^{\circ} \mathrm{C}$ with medium DMEM $/ 10 \%$ FBS for cancer 
cell line (MCF7, T47D, and HeLa) and M199/10\% FBS for normal cell line (Vero). Cell suspensions $\left(10^{6} / \mathrm{ml}\right)$ were prepared, and $100 \mu \mathrm{l} /$ well were dispensed into a 96 -well plate giving $10^{4}$ cells/well. The plates were incubated for 24 hours to allow the cells to reattach. Pyrazolines were initially formulated at $10^{5} \mu \mathrm{g} /$ $\mathrm{ml}$ in DMSO. These samples were diluted with a culture medium to give six serial concentration: $200,100,50,25,12.5$, and 6.25 $\mu \mathrm{g} / \mathrm{ml}$. Aliquots $(100 \mu \mathrm{l})$ of each concentration were added to the wells. After further incubation for 24 hours, the cell viability was evaluated using the MTT assay. The culture medium on plates was removed and washed with PBS. A solution of MTT in PBS was prepared at $50 \mathrm{mg} / 10 \mathrm{ml}$. Aliquots $(1 \mathrm{ml})$ of MTT solution were diluted with $9.5-\mathrm{ml}$ culture medium. Aliquots $(100 \mu \mathrm{l})$ of diluted MTT were added to the wells and incubated for 4 hours. A total of $100 \mu \mathrm{l}$ SDS stopper $10 \%$ in $0.1 \mathrm{~N} \mathrm{HCl}$ was added into each well and left overnight. Absorbance readings were performed by ELISA reader at $595 \mathrm{~nm}$. Cell viability and $\mathrm{IC}_{50}$ value were calculated.

\section{Docking study}

The three-dimensional (3D) structure of pyrazolines A-C was drawn using GaussView 5.0 and optimized using Gaussian 09 with DFT/B3LYP method and 6-31G basis set. The 3D crystal structure of the EGFR domain bound to Erlotinib was retrieved from the protein data bank (PDB ID: 1M17). The preparation of ligand and protein was conducted using Chimera. Redocking and docking were performed with Autodock Tools (ADT) and Autodock 4 in a $45 \times 45 \times 45 \AA$ grid box with a spacing of $0.375 \AA$ using Lamarckian Genetic Algorithm. The redocking analysis was successfully performed when the RMSD value was $<2 \AA$ (Huey et al., 2007). A hundred molecular docking poses for each ligand were ranked based on their docking score. The scoring function

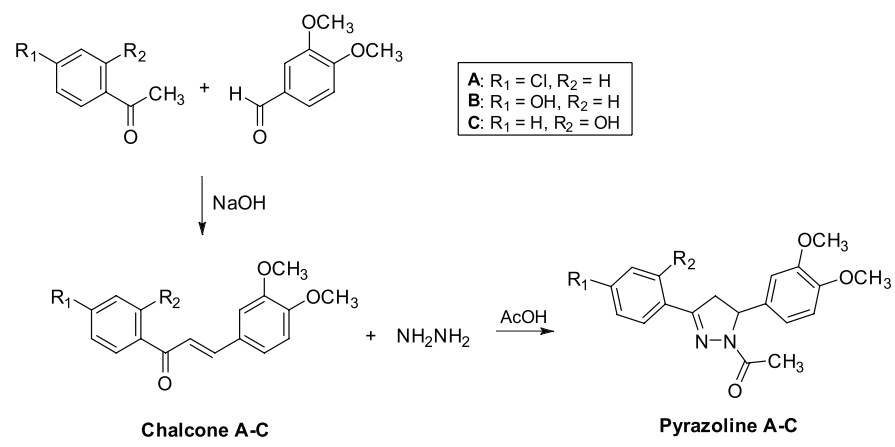

Figure 2. A synthetic scheme of pyrazoline A-C in AutoDock was used to predict the binding affinity of the ligand to the receptor. The conformation with the lowest binding energy was chosen as the most suitable conformation. The docking result was visualized using ADT and Discovery Studio Visualizer.

\section{RESULTS AND DISCUSSION}

The synthesis of chalcone A-C (Fig. 2) was accomplished via the aldol condensation reaction with the addition of sodium hydroxide as a basic catalyst to afford products in excellent yield and purity. Those syntheses were carried out according to the literature (Susanti et al., 2012) with slight modification. Table 1 presents the physical data of the chalcones. The characterization of the synthesized chalcones was conducted by GC-MS, FTIR, and NMR spectrometers. The MS spectra confirmed the molecular weight of the desired chalcones. Characteristic molecular ion peaks $\left(\mathrm{M}^{+}\right.$and $\left.\mathrm{M}^{+2}\right)$ with the height ratio of 3:1 were observed in chalcone A. This confirmed the presence of two chlorine isotopes, ${ }^{35} \mathrm{Cl}$ and ${ }^{37} \mathrm{Cl}$. The IR spectra displayed some important peaks. The presence of $\mathrm{C}_{\mathrm{sp2}}-\mathrm{H}$ bending band at $979-987 \mathrm{~cm}^{-1}$ for transdisubstituted alkene and the absence of $\mathrm{C}-\mathrm{H}$ aldehyde stretching bands confirmed that chalcone $\mathbf{A}-\mathbf{C}$ were correctly achieved. The ${ }^{1} \mathrm{H}-\mathrm{NMR}$ spectra of chalcone displayed two doublet signals with $J$ (coupling constant) value of $15.55 \mathrm{~Hz}$ proving the presence of alkene protons with a trans coupling (Raza et al., 2016). Signals that corresponded with the trans-alkene carbons were also observed in ${ }^{13} \mathrm{C}$-NMR spectra.

The cyclocondensation reaction of the chalcone $\mathbf{A}-\mathbf{C}$ and hydrazine hydrate with the addition of glacial acetic acid produced $N$-acetyl pyrazoline A-C (Fig. 2). The obtained pyrazolines have high yield and purity. Table 1 reports the physical data of these products. The structure of pyrazoline $\mathbf{A}-\mathbf{C}$ was confirmed by several important spectral changes. The mass spectra confirmed the molecular weight of the synthesized pyrazolines. The IR spectra showed the absence of trans-disubstituted alkene at 978 $\mathrm{cm}^{-1}$ as well as the presence of new absorption peaks for $\mathrm{C}=\mathrm{N}$ $\left(\sim 1,597 \mathrm{~cm}^{-1}\right)$ and $\mathrm{C}-\mathrm{N}\left(\sim 1,142 \mathrm{~cm}^{-1}\right)$ confirming the formation of a pyrazoline ring. The ${ }^{1} \mathrm{H}-\mathrm{NMR}$ spectra displayed the existence of characteristic signals with AMX spin system due to the diastereotopic nature of methylene protons on the pyrazoline ring (Suma et al., 2017). Thus, their splitting patterns came as a doublet of doublets at the region of $\delta 3$ and 4 ppm. Furthermore, the $\mathrm{CH}$ proton on the pyrazoline ring arose as a doublet of doublet at the region of $\delta 5 \mathrm{ppm}$ owing to vicinal coupling with methylene protons. The ${ }^{13} \mathrm{C}$-NMR spectra confirmed the absence signals of trans-alkene carbons and the appearing signals of carbons on the pyrazoline ring.

Table 1. Physical data of all synthesized compounds.

\begin{tabular}{lccccccc}
\hline Compound & $R_{1}$ & $R_{2}$ & Molecular formula & Molecular weight & Yield (\%) & Purity (\%) & Melting Point $\left({ }^{\circ} \mathbf{C}\right)$ \\
\hline Chalcone $\mathrm{A}$ & $\mathrm{Cl}$ & $\mathrm{H}$ & $\mathrm{C}_{17} \mathrm{H}_{15} \mathrm{ClO}_{3}$ & 302.75 & 93.19 & 97.72 & $99.2-99.6$ \\
Chalcone B & $\mathrm{OH}$ & $\mathrm{H}$ & $\mathrm{C}_{17} \mathrm{H}_{16} \mathrm{O}_{4}$ & 284.31 & 84.51 & 100.00 & $199.0-201.0$ \\
Chalcone $\mathrm{C}$ & $\mathrm{H}$ & $\mathrm{OH}$ & $\mathrm{C}_{17} \mathrm{H}_{16} \mathrm{O}_{4}$ & 284.31 & 45.07 & 100.00 & $103.2-106.0$ \\
Pyrazoline $\mathrm{A}$ & $\mathrm{Cl}$ & $\mathrm{H}$ & $\mathrm{C}_{19} \mathrm{H}_{19} \mathrm{ClN}_{2} \mathrm{O}_{3}$ & 358.82 & 97.28 & 91.90 & $128.0-129.3$ \\
Pyrazoline B & $\mathrm{OH}$ & $\mathrm{H}$ & $\mathrm{C}_{19} \mathrm{H}_{20} \mathrm{~N}_{2} \mathrm{O}_{4}$ & 340.38 & 88.128 & 83.66 & $219.0-221.0$ \\
Pyrazoline C & $\mathrm{H}$ & $\mathrm{OH}$ & $\mathrm{C}_{19} \mathrm{H}_{20} \mathrm{~N}_{2} \mathrm{O}_{4}$ & 340.38 & 93.14 & 98.96 & $137.2-139.8$ \\
\hline
\end{tabular}


The synthesized pyrazolines $\mathbf{A}-\mathbf{C}$ were evaluated as anticancer agents using MTT against breast cancer lines (MCF7 and T47D), the cervical cancer line (HeLa), and the normal cell line (Vero). Table 2 summarizes the percentage of cell growth inhibition of pyrazolines $\mathbf{A}$ and $\mathbf{B}$. This result shows a correlation between sample concentrations with the percentage of cell growth inhibition: higher concentration resulted in less cell growth. Thus, the inhibition percentage is increasing; this is understandable because typically the more concentrated the compound is, the more toxic it becomes.

The percentage of cell growth inhibition was converted into the $\mathrm{IC}_{50}$ value. The activity of compounds on their cell growth inhibition is classified into three categories, i.e., active $\left(\mathrm{IC}_{50}<20\right.$ $\mu \mathrm{g} / \mathrm{ml})$, moderate $\left(\mathrm{IC}_{50} 20-100 \mu \mathrm{g} / \mathrm{ml}\right)$, and inactive $\left(\mathrm{IC}_{50}>100 \mu \mathrm{g} /\right.$ $\mathrm{ml}$ ) (Tanamatayarat et al., 2003). Table 3 shows the $\mathrm{IC}_{50}$ values of the synthesized pyrazoline $\mathbf{A}-\mathbf{C}$ and commercial drugs. According to the reference stated above, pyrazoline $\mathbf{A}$ has moderate activity in the inhibition of all tested cancer cell line MCF7 ( $\mathrm{IC}_{50} 40.47 \mu \mathrm{g} /$ $\mathrm{ml}$ ), T47D ( $\mathrm{IC}_{50} 26.51 \mu \mathrm{g} / \mathrm{ml}$ ), and HeLa ( $\left.\mathrm{IC}_{50} 31.19 \mu \mathrm{g} / \mathrm{ml}\right)$. The most potent activity of pyrazoline $\mathbf{A}$ is against the breast cancer cell line T47D. Pyrazoline $\mathbf{B}$ is inactive in the inhibition of all tested cancer cell lines $\left(\mathrm{IC}_{50}>100 \mu \mathrm{g} / \mathrm{ml}\right)$. Despite its inactivity, pyrazoline $\mathbf{B}$ is deemed selective as compared with its activity against normal cell Vero $\left(\mathrm{IC}_{50} 44 \times 10^{3} \mu \mathrm{g} / \mathrm{ml}\right)$. This compound has a selectivity index of 64.6, 16.3, and 5.8 against MCF7, T47D, and HeLa, respectively. On the other hand, pyrazoline $\mathbf{C}$ has moderate activity in the inhibition of MCF7 ( $\mathrm{IC}_{50} 94.02 \mu \mathrm{g} /$ $\mathrm{ml}$ ); however, it is inactive against T47D and HeLa. Pyrazoline

Table 2. Percentage of cell growth inhibition.

\begin{tabular}{ccccc}
\hline \multirow{2}{*}{ Pyrazoline } & $\begin{array}{c}\text { Concentration } \\
(\boldsymbol{\mu} \mathbf{g} / \mathbf{m l})\end{array}$ & MCF7 & T47D & HeLa \\
\cline { 3 - 5 } & 200 & 91.81 & 99.04 & 99.22 \\
100 & 77.92 & 97.12 & 81.99 \\
$\mathrm{~A}$ & 50 & 56.40 & 75.08 & 64.29 \\
& 25 & 28.92 & 44.83 & 47.28 \\
& 12.5 & 18.85 & 15.02 & 16.89 \\
& 6.25 & 4.96 & 4.79 & 5.36 \\
& 200 & 31.96 & - & 13.52 \\
& 100 & 31.61 & 10.81 & 10.42 \\
& 50 & 27.46 & 10.91 & 9.04 \\
$\mathrm{~B}$ & 25 & 15.18 & 4.14 & 6.02 \\
& 12.5 & 11.25 & 1.68 & 3.86 \\
& 6.25 & 8.51 & 1.82 & - \\
\hline
\end{tabular}

Table 3. $\mathrm{IC}_{50}$ values of the tested compounds.

\begin{tabular}{lccc}
\hline \multirow{2}{*}{ Entry } & \multicolumn{3}{c}{ IC $_{\mathbf{5 0}}$ value $(\boldsymbol{\mu g} / \mathbf{m L})$} \\
\cline { 2 - 4 } & MCF7 & T47D & HeLa \\
\hline Pyrazoline A & 40.47 & 26.51 & 31.19 \\
Pyrazoline B & 680.00 & 2702.00 & 7642.00 \\
Pyrazoline C & 94.02 & 764.89 & 269.47 \\
Doxorubicin & 3.04 & 10.58 & - \\
Cisplatin & - & - & 18.39 \\
\hline
\end{tabular}

C is also deemed selective as compared with normal cell Vero $\left(\mathrm{IC}_{50} 9 \times 10^{3} \mu \mathrm{g} / \mathrm{ml}\right)$ with a selectivity index of $98.1,12.1$, and 34.2 against MCF7, T47D, and HeLa, respectively. Based on this result, the $\mathrm{IC}_{50}$ values of pyrazoline $\mathbf{A}$ against all tested cancer cell lines are shown to be lower than the $\mathrm{IC}_{50}$ values of pyrazolines $\mathbf{B}$ and $\mathbf{C}$. Thus, pyrazoline $\mathbf{A}$ is a better anticancer candidate than the others. The difference in their activities is due to the presence of functional groups attached to the molecule. Pyrazoline A with the presence of the halogen $p$-Cl substituent on the benzene A-ring displayed more potent activity. Meanwhile, the presence of a hydroxyl substituent on the benzene A-ring of pyrazoline $\mathbf{B}$ and $\mathbf{C}$ decreased their activity.

A molecular docking study was performed to understand how pyrazolines interact with the receptor. An EGFR receptor was used as the protein is often overexpressed in breast and cervical cancer (Masuda et al., 2012; Mubeen et al., 2015). Other studies also reported the use of the EGFR receptor on the docking molecule of pyrazoline derivatives (Lv et al., 2010; Yang et al., 2013). The redocking analysis of EGFR with the original ligand (Erlotinib) showed its binding site on the MET769 residue. This binding site was then used to perform a docking simulation of the pyrazoline compounds. The binding models of pyrazolines with EGFR are shown in Fig 3 and the result was summarized in Table 4.

Pyrazoline $\mathbf{A}$ and $\mathbf{C}$ is nicely bound to the EGFR receptor through hydrogen bond with the side chain of MET769 residue. The binding energy of pyrazoline $\mathbf{A}$ is $-7.24 \mathrm{kcal} / \mathrm{mol}$. The oxygen atom on $m-\mathrm{OCH}_{3}$ of ring $\mathrm{B}$ contributes to the hydrogen bonding interaction with the hydrogen atom on the side chain of MET769 (distance: $1.946 \AA$ ). The $\pi$-cation interaction occurred between ring A and the LYS721 residue indicates that the presence of ring A on pyrazoline has enhanced the interaction of ligand and receptor. Compared with pyrazoline $\mathbf{A}$, the interaction between pyrazoline $\mathbf{C}$ and EGFR receptor is less preferable which is a)
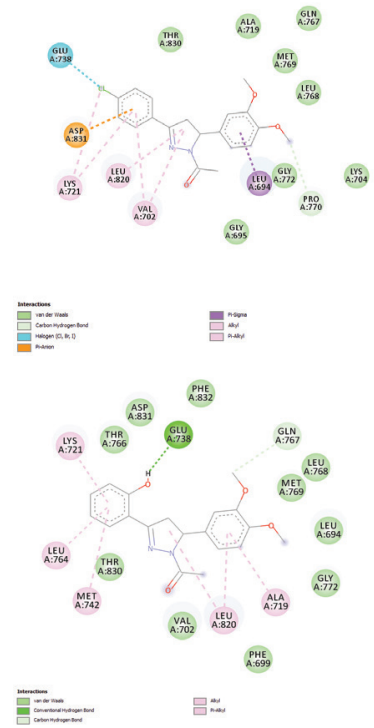

b)
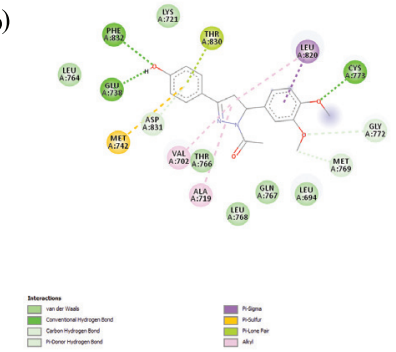

d)

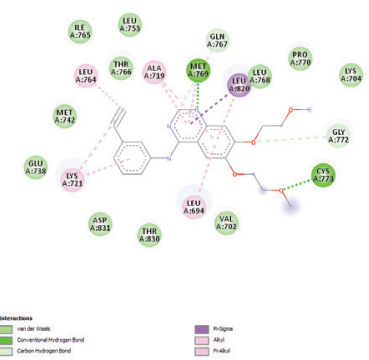

Figure 3. 2D molecular docking model of the EGFR receptor with (a) pyrazoline $\mathbf{A}$, (b) pyrazoline $\mathbf{B}$, (c) pyrazoline $\mathbf{C}$, and (d) Erlotinib. 
Table 4. Docking molecular result.

\begin{tabular}{|c|c|c|}
\hline Compound & $\begin{array}{c}\text { Energy (FEB) } \\
(\text { kcal/mol) }\end{array}$ & Interaction \\
\hline \multirow[t]{7}{*}{ A } & -7.24 & H-Bond: MET769 $(1.946 \AA)^{*}$ \\
\hline & & $\pi$-cation: LYS721* \\
\hline & & CHB: PRO770 \\
\hline & & Halogen: GLU738 \\
\hline & & $\pi$-anion: ASP831 \\
\hline & & $\pi-\sigma:$ LEU694 \\
\hline & & Alkyl/ $\pi$-alkyl: LYS721, LEU820, VAL702 \\
\hline \multirow[t]{8}{*}{ B } & -7.49 & $\begin{array}{l}\text { H-Bond: GLU738 }(1.608 \AA)^{*} \text {, CYS773 } \\
(2.074 \AA)^{*}\end{array}$ \\
\hline & & $\pi$-cation: LYS721* \\
\hline & & H-Bond: GLU738, CYS773, PHE832 \\
\hline & & CHB/ $\pi$-HB: ASP831, MET769, GLY772 \\
\hline & & $\pi-\sigma:$ LEU 820 \\
\hline & & $\pi$-Sulfur: MET742 \\
\hline & & $\pi$-Lone Pair: THR830 \\
\hline & & Alkyl: VAL702, ALA719, LEU820 \\
\hline \multirow[t]{5}{*}{$\mathrm{C}$} & -7.15 & $\begin{array}{l}\text { H-Bond: GLU738 (1.916 §)*, MET769 } \\
(1.986 \AA)^{*}\end{array}$ \\
\hline & & $\pi$-cation: LYS721* \\
\hline & & H-Bond: GLU738 \\
\hline & & CHB: GLN767 \\
\hline & & $\begin{array}{l}\text { Alkyl/ } \pi \text {-alkyl: ALA719, LYS721, LEU764, } \\
\text { MET742, LEU820 }\end{array}$ \\
\hline \multirow[t]{7}{*}{ Erlotinib } & -7.45 & H-Bond: MET769 (1.946 §̊)* \\
\hline & & $\pi$-cation: LYS721* \\
\hline & & CHB: PRO770 \\
\hline & & Halogen: GLU738 \\
\hline & & $\pi$-anion: ASP831 \\
\hline & & $\pi-\sigma:$ LEU694 \\
\hline & & Alkyl/ $\pi$-alkyl: LYS721, LEU820, VAL702 \\
\hline
\end{tabular}

*Visualized by Autodock Tools.

showed from its binding energy of $-7.15 \mathrm{kcal} / \mathrm{mol}$. The hydrogen bonding interaction occurred between oxygen atom on $m-\mathrm{OCH}_{3}$ of ring B with the hydrogen atom on the side chain of MET769 residue (distance: $1.986 \AA$ ). The $\pi$-cation interaction is observed between ring $\mathrm{A}$ and the LYS721 residue. Meanwhile, there is no interaction between pyrazoline $\mathbf{B}$ and MET769 residue which led to the conclusion that pyrazoline $\mathbf{B}$ is the less active compound among the others. The molecular docking result together with the cytotoxicity evaluation data infers that pyrazoline $\mathbf{A}$ is a better anticancer agent.

\section{CONCLUSION}

The novel $\mathrm{N}$-acetyl pyrazoline derivatives containing methoxy groups obtained from veratraldehyde were successfully synthesized in excellent yield and purity by the cyclocondensation of chalcones and hydrazine hydrate in glacial acetic acid. Cytotoxicity evaluation revealed that the presence of a halogen substituent such as chloro on a pyrazoline derivative (pyrazoline A) increased its cytotoxic activity against some cancer cell lines, while the presence of hydroxyl substituent (pyrazoline $\mathbf{B}$ and $\mathbf{C}$ ) decreased the anticancer activity. The molecular docking study showed that pyrazoline A could nicely bind to the active site of the EGFR receptor via hydrogen bonding with MET769 and $\pi$-cation interaction with LYS721.

\section{ACKNOWLEDGMENTS}

We are grateful for the financial support provided by The Ministry of Research, Technology and Higher Education (Kemenristekdikti) of The Republic Indonesia through Hibah Penelitian Unggulan UGM (Contract No: 87/UN1/DITLIT/DITLIT/LT/2018).

\section{REFERENCES}

Ahmad A, Husain A, Khan SA, Mujeeb M, Bhandari A. Synthesis, antimicrobial and antitubercular activities of some novel pyrazoline derivatives. J Saudi Chem Soc, 2016; 20:577-84.

Beyhan N, Kocyigit-Kaymakcioglu B, Gümrü S, Aricioglu F. Synthesis and anticonvulsant activity of some 2-pyrazolines derived from chalcones. Arabian J Chem, 2013; 44:S2073-81.

Huey R, Morris GM, Olson AJ, Goodsell DS. A semiempirical free energy force field with charge-based desolvation. J Comput Chem, 2007; 28:1545-614.

Karabacak M, Altıntop MD, Çifţi HI, Koga R, Otsuka M, Fujita M, Özdemir A. Synthesis and evaluation of new pyrazoline derivatives as potential anticancer agents. Molecules, 2015; 20:19066-84.

Karad SC, Purohit VB, Thakor P, Thakkar VR, Raval DK. Novel morpholinoquinoline nucleus clubbed with pyrazoline scaffolds: Synthesis, antibacterial, antitubercular and antimalarial activities. Eur J Med Chem, $216 ; 112: 270-9$.

Kementerian Kesehatan RI. Situasi Penyakit Kanker. 2015. Available via http://www.depkes.go.id/download.php?file=download/ pusdatin/buletin/buletin-kanker.pdf (Accessed 10 July 2018).

Kumar A, Varadaraj BG, Singla RK. Synthesis and evaluation of antioxidant activity of novel 3,5-disubstituted-2-pyrazolines. Bull Fac Pharm Cairo Univ, 2013; 51:167-73.

Lv PC, Li HQ, Sun J, Zhou Y, Zhu HL. Synthesis and biological evaluation of pyrazole derivatives containing thiourea skeleton as anticancer agents. Bioorg Med Chem, 2010; 18:4606-14.

Masuda H, Zhang D, Bartholomeusz C, Doihara H, Hortobagyi GN, Ueno NT. Role of epidermal growth factor receptor in breast cancer. Breast Cancer Res, 2012; 136:331-45.

Mubeen M, Kini SG, Pai KSR. Design, synthesis, antioxidant, and anticancer activity of novel pyrazole derivatives. Der Pharma Chemica 2015; 7:215-23.

Patel K, Karthikeyan C, Solomon VR, Moorthy NSHN, Lee H, Sahu K, Deora GS, Trivedi P. Synthesis of some coumarinyl chalcones and their antiproliferative activity against breast cancer cell lines. Lett Drug Des Discov, 2011; 8:308-11.

Rani M, Yusuf M, Khan SA. Synthesis and in-vitro-antibacterial activity of [5-(furan-2-yl)-phenyl]-4,5-carbothioamide-pyrazolines. J Saudi Chem Soc, 2012; 16:431-6.

Raza AR, Sultan A, Ullah N, Janjua MRSA, Khan KM Fragmentation study of substituted chalcones: gas phase formation of benz1-oxin cation. Mod Chem Appl, 2016; 4:1-6.

Shaaban MR, Mayhoub AS, Farag AM. Recent advances in the therapeutic applications of pyrazolines. Expert Opin Ther Patents, 2012; 22:253-91.

Sharma M, Sharma S, Buddhiraja A, Saxena AK, Nepali K, Bedi PMS. Synthesis and cytotoxicity studies of 3,5-diaryl N-acetyl pyrazolineisatin hybrids. Med Chem Res, 2014; 23:4337-44.

Suma AAT, Wahyuningsih TD, Pranowo D. Synthesis and antibacterial activities of $\mathrm{N}$-phenylpyrazolines from veratraldehyde. Mater Sci Forum, 2017; 901:124-32. 
Susanti EVH, Matsjeh S, Wahyuningsih TD, Mustofa, Redjeki T. Synthesis, characterization and antioxidant activity of 7-hydroxy-3',4'dimethoxyflavone. Indones J Chem, 2012; 12:146-51.

Tanamatayarat P, Limtrakul P, Chunsakaow S, Duangrat C. Screening of some rubiaceous plants for cytotoxicity activity against cervix carcinoma (KB-3-1) cell line. J Pharm Sci, 2003; 27:167-72.

Tian WJ, Huang ML, Qin QF, Chen Q, Fang K, Wang PL. Prognostic impact of epidermal growth factor receptor overexpression in patients with cervical cancer: a meta-analysis. PLoS One, 2016; 11:1-13.

Viveka S, Dinesha, Shama P, Nagaraja GK, Ballav S, Kerkar S Design and synthesis of some new pyrazolyl-pyrazolines as potential antiinflammatory, analgesic and antibacterial agents. Eur J Med Chem, 2015; 101:442-51.
Yang W, Hu Y, Yang YS, Zhang F, Zhang YB, Wang XL, Tang JF, Zhong WQ, Zhu HL. Design, modification and 3D QSAR studies of novel naphthalin-containing pyrazoline derivatives with/without thiourea skeleton as anticancer agents. Bioorg Med Chem, 2013; 21:1050-63.

\section{How to cite this article:}

Wahyuningsih TW, Suma AAT, Astuti E. Synthesis, anticancer activity, and docking study of $N$-acetyl pyrazolines from veratraldehyde. J Appl Pharm Sci, 2019; 9(03):014-020. 